(c) American Dairy Science Association, 2005.

\title{
Straw-Thawing Method Interacts with Sire and Extender to Influence Sperm Motility and Conception Rates of Dairy Cows
}

\author{
J. M. DeJarnette and C. E. Marshall \\ Select Sires, Inc., Plain City, OH, 43064
}

\section{ABSTRACT}

Influence of interactions of straw-thawing method with sire and extender type (milk or egg yolk-based) on postthaw sperm motility and conception rates of dairy cows was assessed. In experiment 1 , sperm from 10 Holstein sires were frozen in egg yolk citrate and heated whole-milk extenders using a split-ejaculate technique. Straws were thawed in a $37^{\circ} \mathrm{C}$ water bath with or without $3 \mathrm{~min}$ of exposure to a $37^{\circ} \mathrm{C}$ warming plate while wrapped in a paper towel (air-thaw). Percentage of motile sperm was assessed after $1 \mathrm{~min}$ and $3 \mathrm{~h}$ of incubation at $37^{\circ} \mathrm{C}$. In experiment 2 , sperm from 3 Holstein sires were frozen in egg-yolk citrate and a nonheated whole milk extender using a split-ejaculate technique. Straws were thawed and motility was assessed as in experiment 1 . Conception rates $(\mathrm{n}=475)$ were compared in a single herd of Holstein cows after thawing straws in $35^{\circ} \mathrm{C}$ water for $45 \mathrm{~s}$ or after air-thawing by wiping straws with a paper towel upon removal from the storage vessel and placing directly into the insemination gun. In each experiment, interactions between thaw method and sire, extender type, or both, indicated that conditions may be created that facilitate sperm tolerance of air-thaw procedures. When a significant thaw method effect was detected in either experiment, air-thaw was consistently associated with the lesser measure of sperm motility, conception, or both. In conclusion, although some sire $\times$ extender combinations seem to be tolerant of air-thaw procedures, other combinations are more sensitive, resulting in reduced postthaw sperm survival, conception rates of cows, or both, in response to air-thaw.

(Key words: artificial insemination, semen extender, semen thawing, sperm cryopreservation)

Abbreviation key: EYC = egg yolk-citrate extender, HWM = heated whole milk, $\mathbf{N H W M}=$ nonheated whole milk extender.

Received April 1, 2005.

Accepted July 12, 2005.

Corresponding author: J. M. DeJarnette; e-mail: jmdejarnette@ selectsires.com.

\section{INTRODUCTION}

Most commercially available bovine semen is cryopreserved in either an egg yolk- or milk-based extender. Lactenin and other enzymes in milk are toxic to spermatozoa and must be denatured before extender preparation (Flipse et al., 1954). This denaturation is typically accomplished by heating milk to 92 to $95^{\circ} \mathrm{C}$ for $10 \mathrm{~min}$ (Thacker and Almquist, 1953). Unpublished studies in our laboratory have yielded an alternative proprietary method to deactivate these toxic compounds prior to extender preparation. Additional unpublished field trials confirmed that semen processed in this nonheated milk-based extender achieved comparable conception rates to a standard egg yolk-based extender when straws were thawed in 33 to $35^{\circ} \mathrm{C}$ water for a minimum of $45 \mathrm{~s}$.

The preponderance of published studies indicate that, irrespective of extender type, greater postthaw sperm survival is achieved when $0.5-\mathrm{mL}$ French straws are thawed in 33 to $35^{\circ} \mathrm{C}$ water for a minimum of $45 \mathrm{~s}$ (Berndston et al., 1976; Senger, 1980; Chandler et al., 1984). Most bovine AI organizations in the United States have adopted this procedure as the standard straw-thawing method. Other studies, however, indicate that extenders, freezing protocols, or both, may be altered such that a modified air-thaw procedure may be a more convenient alternative (Pocket Thaw; Bean, 1972; Kaproth et al., 2002, 2005b). Lack of consistency in semen-thawing recommendations made by various AI centers presents an opportunity for user error when straws processed by one organization are inadvertently thawed by alternative procedures prescribed by another organization. In addition, the ability of a given semen sample to tolerate the slower thaw rate induced by air-thaw may be highly sire- or ejaculate-dependent (DeJarnette et al., 2000).

The objectives of the present study were to investigate the influence of interactions of straw-thawing method $\left(35^{\circ} \mathrm{C}\right.$ water vs. ambient air) with sire or extender type (milk- and egg yolk-based) on postthaw sperm motility and conception rates of cryopreserved bovine semen. 


\section{MATERIALS AND METHODS}

\section{Experiment 1}

Using a split-ejaculate technique, single ejaculates collected by artificial vagina from 10 Holstein sires were cryopreserved in either egg-yolk-citrate (EYC) or heated whole milk (HWM) extenders. The EYC extender was composed of a $2.9 \%$ sodium citrate buffer supplemented with $20 \%$ egg yolk (vol/vol). Whole milk was detoxified by heating to 92 to $95^{\circ} \mathrm{C}$ for $10 \mathrm{~min}$ and then filtered through cheesecloth before extender preparation. Both extenders were prepared with glycerolated and nonglycerolated fractions containing 14 or $0 \%$ glycerol ( $\mathrm{vol} / \mathrm{vol})$, respectively. Two aliquots containing $0.28 \times 10^{9}$ spermatozoa were removed from each ejaculate and placed in $15-\mathrm{mL}$ centrifuge tubes containing $7 \mathrm{~mL}$ (one-half of total volume) of each respective nonglycerolated extender held at $35^{\circ} \mathrm{C}$. Samples were placed in a $200-\mathrm{mL}$ water bath and allowed to equilibrate to $5^{\circ} \mathrm{C}$ over a 2 -h period. An equal volume $(7 \mathrm{~mL})$ of each respective glycerolated fraction was added in aliquots of $1.5,2.5$, and $3.0 \mathrm{~mL}$ at 10 -min intervals. The final dilution yielded a sperm concentration of $10 \times 10^{6}$ per $0.5-\mathrm{mL}$ French straw. Straws were frozen in liquid nitrogen vapor at rates previously described by DeJarnette et al. (2000).

Sample straws from each sire $\times$ extender combination were subjected to 2 thawing procedures before evaluation of sperm motility. Air-thawed straws were removed from the liquid nitrogen storage vessel, wrapped in a paper towel, and placed on a thermostatically controlled warming plate set at $37^{\circ} \mathrm{C}$ for $3 \mathrm{~min}$ before being plunged into a $37^{\circ} \mathrm{C}$ water bath. These procedures were not necessarily designed to mimic the pocket-thaw procedure, which would have inherent variation in thaw rates due to variance in ambient temperature, humidity, insulating characteristics of clothing material, etc. Rather, the air-thaw procedures were intended to optimize the rate of sperm thaw while minimizing variance in thaw rates. Terminating the air-thaw procedure by plunging the straw in $37^{\circ} \mathrm{C}$ water was performed to equilibrate semen to an optimum temperature for motility assessment. Control straws were plunged directly into a $37^{\circ} \mathrm{C}$ water bath after removal from the storage vessel. Percentage of motile sperm was visually estimated (rounded to the nearest 5\%) after 1 min $(0 \mathrm{~h})$ and $3 \mathrm{~h}$ of incubation at $37^{\circ} \mathrm{C}$ at $200 \times$ magnification using differential interference contrast optics. To minimize effects of straw-to-straw variance in sperm motility that tends to be magnified with incubation time (personal observation), 2 straws were pooled immediately before the 3 -h evaluation, whereas only a single straw was used for the 0 -h evaluation. All evaluations were performed in triplicate.

\section{Experiment 2}

Extender preparation and semen processing. Using a split-ejaculate technique, semen from $3 \mathrm{Hol}-$ stein sires was cryopreserved in either EYC (as in experiment 1) or a nonheated whole milk extender (NHWM). Lactenin in whole milk was detoxified during NHWM preparation using proprietary technology. Both extenders were treated with an antibiotic mixture as prescribed by industry standards (Certified Semen Services, Columbia, MO). As described in experiment 1 , each extender was prepared with a glycerolated and nonglycerolated fraction (14 and $0 \%$ glycerol, vol/vol, respectively) and used in a 2-step fashion. Aliquots containing $1.78 \times 10^{9}$ (Sire K) or $2.67 \times 10^{9}$ (sires L and M) spermatozoa were partially extended (1:3) with the nonglycerolated fraction of each extender held at $35^{\circ} \mathrm{C}$. Partially extended samples were placed in a $250-\mathrm{mL}$ glass beaker containing $200 \mathrm{~mL}$ of $35^{\circ} \mathrm{C}$ water and cooled to $5^{\circ} \mathrm{C}$ over $2 \mathrm{~h}$. After cooling, samples were filled to one-half total volume $(44.4 \mathrm{~mL})$ with the respective nonglycerolated fraction. An equal volume of the respective glycerolated fraction was then slowly added by titration as samples were agitated on a shaker table. Dilution procedures varied by sire (sperm/straw $=10 \times$ $10^{6}$ for sire $\mathrm{K}$ and $15 \times 10^{6}$ for sires $\mathrm{L}$ and $\mathrm{M}$ ) in an attempt to approach threshold sperm numbers and thereby facilitate detection of fertility differences due to semen quality that could otherwise be masked at larger cell-number dosages (Salisbury and VanDemark, 1961; Saacke, 1998). After extension, samples were loaded into color-coded straws (red and yellow), which alternated between extender types across bulls to facilitate blind and nonbiased use by inseminators. Within sire, 160 straws for each color (extender type) were thoroughly mixed before freezing in liquid nitrogen vapor. Effects of extender type and thaw method on postthaw sperm viability were assessed in triplicate using identical procedures as described in experiment 1.

Study herd and treatment allocation. Conception rates were compared in a single herd of approximately 750 Holstein cows having a rolling herd average of $10,525 \mathrm{~kg}$ of milk during the study (Teabow Farms, MD). Cows were visually observed for signs of estrus at least twice daily by experienced herd personnel. Cows detected in standing estrus were assigned to straw color (extender type) and thaw method $\left(35^{\circ} \mathrm{C}\right.$ water vs. air) based on parity and calving date as they were presented for AI 8 to $12 \mathrm{~h}$ later. Straws were either thawed by plunging them in $35^{\circ} \mathrm{C}$ water for a minimum of $45 \mathrm{~s}$ or by an air-thaw procedure, in which straws were removed from the liquid nitrogen storage vessel, wiped with a paper towel, and placed directly in the AI gun. Assembled guns were wrapped in a paper towel and 
Table 1. Descriptive statistics of animals used in experiment 2.

\begin{tabular}{llllc}
\hline Extender type & Thaw method & No. & \multicolumn{2}{l}{ Lactation no. } \\
\hline & & & \multicolumn{2}{c}{ DIM } \\
\cline { 4 - 5 } Egg yolk citrate & Water bath & 116 & $1.9 \pm 0.1$ & $129 \pm 8.3$ \\
& Air & 129 & $1.8 \pm 0.1$ & $140 \pm 7.6$ \\
Nonheated milk & Water bath & 112 & $1.8 \pm 0.1$ & $144 \pm 10.3$ \\
& Air & 118 & $2.0 \pm 0.1$ & $129 \pm 8.1$ \\
\hline
\end{tabular}

placed inside the inseminator's clothing for transport to the cow. A single herdsman-inseminator performed all AI. Within sire, attempts were made to thaw an equal number of straws for each color and thaw method on each breeding day and a running tally was used to ensure treatments, parity, and DIM remained relatively balanced throughout the experiment (Table 1). Treatment information was entered directly into the herd management software program (Dairy Comp 305, Valley Ag Software, Visalia, CA). Cows that returned to estrus were considered not pregnant and cows that failed to return to estrus were diagnosed for pregnancy by palpation of the uterus and its contents at 30 to 50 $\mathrm{d}$ after AI. Relevant insemination and lactation data were electronically exported for statistical analysis.

Due to initial concerns of potential reductions in conception rates, this experiment was conducted in 2 phases. An initial allotment of semen (100 straws per sire) was used during the fall of 2003. Pregnancy data were recovered, and a preliminary analysis performed in February 2004 indicated minor influence of treatments on conception. The second phase of the project was initiated with an additional 75 units per sire distributed to the dairy for use during spring 2004 .

\section{Statistical Analyses}

Semen quality data in both experiments were analyzed in a least-square model including the main effects of sire, extender type, and thaw method in a full factorial design. To further investigate significant sire interactions with greater statistical sensitivity, semen qual- ity data from each experiment were reanalyzed separately for each sire including only the main effects of extender type and thaw method in a full factorial design. In experiment 2 , conception data were analyzed in the above least square model plus additional effects of season of AI, all 2-way interactions of season with previously existing main effects, lactation number (1, 2 , or $\geq 3$ ), DIM at AI, and relative herd-mate deviation for milk production. Nonsignificant interactions and main effects were sequentially removed from the model in descending order of hierarchy and $P$ value, and data were reanalyzed. The Tukey's HSD test was used for all mean comparisons. Mean conception rates were correlated (Pearson's) with mean motility estimates for each sire, extender, and thaw-method combination. All evaluations were performed using SAS JMP Statistical Discovery software (SAS Inst., Inc., Cary, NC).

\section{RESULTS AND DISCUSSION}

\section{Experiment 1}

Extender type and thaw method influenced $(P \leq 0.05)$ postthaw motility after $0 \mathrm{~h}$ incubation at $37^{\circ} \mathrm{C}$ (Table $2)$. Motility after $0 \mathrm{~h}$ incubation was greater $(P \leq 0.05)$ for semen processed in HWM $(76 \pm 0.3 \%)$ than EYC (75 $\pm 0.4 \%$ ) extender. Detection of this small difference in 0 -h motility was likely facilitated by the large sample size (10 sires) and triplicate evaluations; however, such a small difference likely has little biological relevance. Although a 2-percentage point difference in $0 \mathrm{~h}$ motility between warm water-thawed $(77 \pm 0.3 \%)$ and airthawed ( $75 \pm 0.3 \%)$ straws differed $(P \leq 0.01)$, the difference is of questionable biological relevance. Consistent with previous studies (Linford et al., 1976; Saacke et al., 1980; DeJarnette et al., 2000) however, incubation magnified differences in sperm motility and enhanced the ability to detect latent sperm injury due to treatments. Motility after $3 \mathrm{~h}$ of incubation was influenced $(P \leq 0.05)$ by all model effects except the sire $\times$ thaw method interaction (Table 2). Of particular interest was the 3 -way interaction $(P<0.05)$ of sire $\times$ extender type

Table 2. Least squares means ANOVA (experiment 1).

\begin{tabular}{|c|c|c|c|c|c|c|c|}
\hline \multirow[b]{2}{*}{ Source } & \multirow[b]{2}{*}{$\mathrm{df}$} & \multicolumn{3}{|c|}{ Motility (0 h) } & \multicolumn{3}{|c|}{ Motility (3 h) } \\
\hline & & $\begin{array}{l}\text { Sum of } \\
\text { squares }\end{array}$ & $F$ ratio & $P$ & $\begin{array}{l}\text { Sum of } \\
\text { squares }\end{array}$ & $F$ ratio & $P$ \\
\hline Sire & 9 & 59.2 & 1.21 & 0.30 & 733 & 8.3 & $<0.001$ \\
\hline Extender & 1 & 30.0 & 5.54 & 0.02 & 908 & 92.7 & $<0.001$ \\
\hline Sire $\times$ extender & 9 & 32.5 & 0.67 & 0.74 & 776 & 8.8 & $<0.001$ \\
\hline Thaw method & 1 & 140.8 & 26.00 & $<0.001$ & 908 & 92.7 & $<0.001$ \\
\hline Sire $\times$ thaw method & 9 & 30.0 & 0.62 & 0.78 & 109 & 1.2 & 0.28 \\
\hline Extender $\times$ thaw method & 1 & 0.8 & 0.15 & 0.77 & 53 & 5.5 & 0.02 \\
\hline Sire $\times$ extender $\times$ thaw method & 9 & 20.0 & 0.41 & 0.93 & 230 & 2.6 & 0.01 \\
\hline
\end{tabular}


Table 3. Effects of sire, extender type, and thawing method on postthaw incubated $(3 \mathrm{~h})$ sperm motility ${ }^{1}$ (experiment 1).

\begin{tabular}{|c|c|c|c|c|c|c|}
\hline \multirow[b]{3}{*}{ Sire } & \multicolumn{4}{|c|}{ Extender type } & & \\
\hline & \multicolumn{2}{|c|}{ Egg yolk citrate } & \multicolumn{2}{|c|}{ Heated whole milk } & \multicolumn{2}{|c|}{ Total } \\
\hline & Water-thaw & Air-thaw & Water-thaw & Air-thaw & Water-thaw & Air-thaw \\
\hline A & $37 \pm 1.7^{\mathrm{a}}$ & $35 \pm 2.9^{\mathrm{a}}$ & $33 \pm 1.7^{\mathrm{ab}}$ & $23 \pm 3.3^{b}$ & $35 \pm 1.3^{\mathrm{e}}$ & $29 \pm 3.3^{\mathrm{f}}$ \\
\hline B & $35 \pm 0.0^{\mathrm{a}}$ & $33 \pm 1.7^{\mathrm{a}}$ & $33 \pm 1.7^{\mathrm{a}}$ & $22 \pm 1.7^{\mathrm{b}}$ & $34 \pm 0.8^{\mathrm{e}}$ & $28 \pm 2.8^{\mathrm{f}}$ \\
\hline $\mathrm{C}$ & $35 \pm 0.0^{\mathrm{a}}$ & $35 \pm 0.0^{\mathrm{a}}$ & $30 \pm 2.9^{\mathrm{a}}$ & $20 \pm 2.9^{c}$ & $33 \pm 1.7^{\mathrm{e}}$ & $28 \pm 3.6^{\mathrm{f}}$ \\
\hline D & $37 \pm 3.3$ & $30 \pm 0.0$ & $33 \pm 1.7$ & $30 \pm 0.0$ & $35 \pm 1.8^{\mathrm{e}}$ & $30 \pm 0.0^{\mathrm{f}}$ \\
\hline $\mathrm{E}$ & $35 \pm 0.0^{\mathrm{a}}$ & $30 \pm 0.0^{b}$ & $22 \pm 1.7^{\mathrm{c}}$ & $10 \pm 0.0^{\mathrm{d}}$ & $28 \pm 3.1^{\mathrm{e}}$ & $20 \pm 4.5^{\mathrm{f}}$ \\
\hline $\mathrm{F}$ & $32 \pm 1.7$ & $32 \pm 1.7$ & $32 \pm 1.7$ & $28 \pm 1.7$ & $32 \pm 1.1$ & $30 \pm 1.3$ \\
\hline G & $33 \pm 1.7^{\mathrm{a}}$ & $23 \pm 1.7^{\mathrm{b}}$ & $33 \pm 1.7^{\mathrm{a}}$ & $27 \pm 1.7^{\mathrm{ab}}$ & $33 \pm 1.1^{\mathrm{e}}$ & $25 \pm 1.3^{\mathrm{f}}$ \\
\hline $\mathrm{H}$ & $37 \pm 1.7^{\mathrm{a}}$ & $33 \pm 1.7^{\mathrm{ab}}$ & $30 \pm 2.9^{\mathrm{ab}}$ & $25 \pm 0.0^{\mathrm{b}}$ & $33 \pm 2.1^{\mathrm{e}}$ & $29 \pm 2.0^{f}$ \\
\hline I & $30 \pm 0.0$ & $25 \pm 0.0$ & $28 \pm 3.3$ & $25 \pm 2.9$ & $29 \pm 1.5^{\mathrm{h}}$ & $25 \pm 1.3^{\mathrm{i}}$ \\
\hline$J$ & $38 \pm 1.7^{\mathrm{a}}$ & $30 \pm 0.0^{\mathrm{b}}$ & $32 \pm 1.7^{\mathrm{b}}$ & $28 \pm 1.7^{\mathrm{b}}$ & $35 \pm 1.8^{\mathrm{h}}$ & $29 \pm 0.8^{\mathrm{i}}$ \\
\hline Total & $35 \pm 0.6^{\mathrm{e}}$ & $31 \pm 0.8^{\mathrm{f}}$ & $31 \pm 0.9^{f}$ & $24 \pm 1.1^{\mathrm{g}}$ & $33 \pm 0.6^{\mathrm{y}}$ & $27 \pm 0.8^{z}$ \\
\hline
\end{tabular}

${ }^{\mathrm{a}, \mathrm{b}, \mathrm{c}, \mathrm{d}}$ Row means within sire lacking common superscript letters differ $(P<0.05)$.

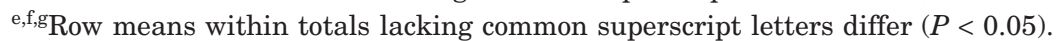

${ }^{\mathrm{h}, \mathrm{i}}$ Row means within totals lacking common superscript letters $\operatorname{differ}(P<0.10)$.

${ }^{\mathrm{y}, \mathrm{z}}$ Overall total means for thaw method across sires and extenders differ $(P<0.01)$.

${ }^{1}$ Using a split-ejaculate technique, semen from 10 Holstein sires was cryopreserved in an egg yolk citrate and a heated whole milk extender. Straws from each sire $\times$ extender combination were thawed in a $37^{\circ} \mathrm{C}$ water bath or air-thawed by wrapping in a paper towel and placing on a $37^{\circ} \mathrm{C}$ warming plate for $3 \mathrm{~min}$. All straws were incubated for $3 \mathrm{~h}$ in a $37^{\circ} \mathrm{C}$ water bath before visual estimation of percentage motile sperm. Procedures were performed in triplicate.

$\times$ thaw method (Table 3). For 7 of 10 sires evaluated, 3 -h motility was negatively influenced $(P \leq 0.05)$ by airthaw for at least 1 of the 2 extenders. Consistent with earlier studies (Berndston et al., 1976; Senger, 1980; Chandler et al., 1984), the magnitude of both extender and thaw method effects varied among sires; however, across extenders, 3 -h motility tended $(P \leq 0.10)$ to be negatively influenced by air-thaw for 9 of 10 sires evaluated.

Previous studies indicate that extender type, glycerol level, and freezing rate may interact to influence the ability of sperm to tolerate a slower thawing rate (Rodriguez et al., 1975; Robbins et al., 1976). Although 3-h sperm motility after air-thaw of EYC extender was less than the warm-water contemporary, it was still comparable with that of warm-water thaw of HWM extender (Table 3). Because only a single freezing rate was evaluated in the present study, which was previously optimized for use with EYC extender and warm water thaw, these results should not be interpreted to imply superiority of either extender type (EYC or HWM). These results, however, support previous conclusions indicating numerous interactions in the semen processing and cryopreservation protocols that can influence sperm tolerance to thaw methods (Rodriguez et al., 1975; Robbins et al., 1976).

\section{Experiment 2}

Motility at $0 \boldsymbol{h}$. In contrast to experiment 1, sperm motility at $0 \mathrm{~h}$ of incubation was influenced by the sire $\times$ extender type interaction $(P<0.01)$ and by the sire $\times$ thaw method interaction $(P<0.01$; Table 4$)$. Numeric trends in 0-h motility favored the warm-water thaw for all sires; however, these differences were only significant for sire L (Table 5), which is consistent with previous conclusions indicating differential sensitivity of individual sires to detrimental effects of air-thaw procedures (DeJarnette et al., 2000).

The sire $\times$ extender type interaction was primarily due to sire $\mathrm{K}$, in which 0 -h motility was greater $(P<$ $0.05)$ in NHWM $(76 \pm 0.8 \%)$ than in EYC $(69 \pm 1.5 \%)$ extender. In contrast, the trend $(P=0.14)$ in sire $\mathrm{L}$ for greater 0 -h motility in EYC $(73 \pm 2 \%)$ than NHWM (69 $\pm 2 \%$ ) is consistent with previous studies that indicate sperm from certain sires will cryopreserve more efficiently in one extender than in another (Thacker and Almquist, 1953; Schenk et al., 1987). Due to the small sample size of the present study ( $\mathrm{n}=3$ sires), these data should not be interpreted to imply superiority of one extender over the other.

Motility at $3 \boldsymbol{h}$. Sperm motility after $3 \mathrm{~h}$ of incubation was only influenced by thawing method; no interaction with sire or extender type was detected (Table 4). Interestingly, effects of thaw method were nearly identical across both sires and extenders and clearly indicate greater latent sperm injury is induced by air-thaw than by warm water thaw (Table 5), which is consistent with earlier studies indicating greater sperm survival is achieved with faster thaw rates (Berndston et al., 1976; Senger, 1980; DeJarnette et al., 2000). 
Table 4. Least squares means ANOVA of treatment effects on sperm motility after 0 and $3 \mathrm{~h}$ of incubation at $37^{\circ} \mathrm{C}$ (experiment 2 ).

\begin{tabular}{|c|c|c|c|c|c|c|c|}
\hline \multirow[b]{2}{*}{ Source } & \multirow[b]{2}{*}{$\mathrm{df}$} & \multicolumn{3}{|c|}{ Motility at $0 \mathrm{~h}$} & \multicolumn{3}{|c|}{ Motility at $3 \mathrm{~h}$} \\
\hline & & $\begin{array}{l}\text { Sum of } \\
\text { squares }\end{array}$ & $F$ ratio & $P$ & $\begin{array}{l}\text { Sum of } \\
\text { squares }\end{array}$ & $F$ ratio & $P$ \\
\hline Sire & 2 & 109.7 & 9.98 & $<0.001$ & 16.7 & 0.55 & 0.59 \\
\hline Extender & 1 & 25.0 & 4.50 & 0.04 & 11.1 & 0.73 & 0.40 \\
\hline Sire $\times$ extender & 2 & 179.2 & 16.13 & $<0.001$ & 22.2 & 0.73 & 0.49 \\
\hline Thaw method & 1 & 136.1 & 24.50 & $<0.001$ & 1469.4 & 96.18 & $<0.001$ \\
\hline Sire $\times$ thaw method & 2 & 68.1 & 6.13 & $<0.01$ & 22.2 & 0.73 & 0.49 \\
\hline Extender $\times$ thaw method & 1 & 2.8 & 0.50 & 0.49 & 0.00 & 0.00 & 1.00 \\
\hline Sire $\times$ extender $\times$ thaw method & 2 & 9.7 & 0.88 & 0.43 & 16.7 & 0.55 & 0.59 \\
\hline
\end{tabular}

Conception rates. Constraints associated with conducting this experiment in a single location limited the number of straws that could be used for each sire $x$ extender $\times$ thaw method combination. Therefore, the statistical power to detect this 3-way interaction was limited even though the experimental design dictated it should be considered. Surprisingly, conception rate differences were larger than anticipated and the 3-way interaction of sire $\times$ extender type $\times$ thaw method was determined to be significant $(P<0.05$; Table 6$)$. The interaction was primarily a function of reduced conception in response to the air-thaw procedure when using the NHWM extender for sire L and with the EYC extender for sire $\mathrm{M}$ (Table 7). Although conception rates of several sire $x$ extender combinations were not affected by the air-thaw procedure (sires $\mathrm{K}$ and $\mathrm{M}$ in NHWM, sire L in EYC), it is not readily apparent how these air-thaw-tolerant sires (ejaculates) can be accurately identified and communicated for use by the end user. Therefore, the significant negative effect of airthaw on conception rates of 1 of 3 sires for each extender type (sire L in NHWM, sire M in EYC) tends not to support the use of air-thaw of straws for these extenders.

As most studies evaluating sperm viability after airthaw have indicated compromised survival compared with warm water thaw, few researchers have risked reduced conception rates to carry these studies further to field fertility trials. Therefore, direct comparisons of conception potential after warm water or air-thaw are limited. In a recent trial, Kaproth et al. (2005a,b) observed a significant reduction in sperm motility in response to pocket-thaw of semen processed in a HWM extender; however, the nonreturn rates of virgin dairy heifers were not affected by thaw method. The contrasting results between the present study and the similarly designed trial of Kaproth et al. (2005a,b) may be explained by a number of factors. Despite the many

Table 5. Effects of sire, extender type, and thawing method (water or air) on postthaw sperm motility ${ }^{1}$ (experiment 2).

\begin{tabular}{|c|c|c|c|c|c|c|c|}
\hline \multirow[b]{3}{*}{ Motility } & \multirow[b]{3}{*}{ Sire } & \multicolumn{4}{|c|}{ Extender type and thaw method } & & \\
\hline & & \multicolumn{2}{|c|}{ Egg yolk citrate } & \multicolumn{2}{|c|}{ Nonheated milk } & \multicolumn{2}{|c|}{ Total } \\
\hline & & Water & Air & Water & Air & Water & Air \\
\hline \multirow[t]{4}{*}{$0 \mathrm{~h}$} & $\mathrm{~K}$ & $72 \pm 1.7^{\mathrm{ab}}$ & $67 \pm 1.7^{\mathrm{b}}$ & $77 \pm 1.7^{\mathrm{a}}$ & $75 \pm 0.0^{\mathrm{a}}$ & $74 \pm 1.5$ & $71 \pm 2.0$ \\
\hline & $\mathrm{L}$ & $77 \pm 1.7^{\mathrm{a}}$ & $70 \pm 0.0^{\mathrm{bc}}$ & $73 \pm 1.7^{\mathrm{ab}}$ & $65 \pm 0.0^{c}$ & $75 \pm 1.3^{\mathrm{d}}$ & $68 \pm 1.1^{\mathrm{e}}$ \\
\hline & M & $75 \pm 0.0$ & $73 \pm 1.7$ & $77 \pm 1.7$ & $77 \pm 1.7$ & $76 \pm 0.8$ & $75 \pm 1.3$ \\
\hline & Total & $74 \pm 1.0$ & $70 \pm 1.2$ & $76 \pm 1.0$ & $72 \pm 1.9$ & $75 \pm 0.7^{\mathrm{d}}$ & $71 \pm 1.1^{\mathrm{e}}$ \\
\hline \multirow[t]{5}{*}{$3 \mathrm{~h}$} & & & & & & & \\
\hline & $\mathrm{K}$ & $28 \pm 1.7^{\mathrm{a}}$ & $17 \pm 1.7^{\mathrm{b}}$ & $28 \pm 1.7^{\mathrm{a}}$ & $17 \pm 1.7^{\mathrm{b}}$ & $28 \pm 1.1^{\mathrm{d}}$ & $17 \pm 1.1^{\mathrm{e}}$ \\
\hline & $\mathrm{L}$ & $30 \pm 0.0^{\mathrm{a}}$ & $20 \pm 0.0^{\mathrm{b}}$ & $28 \pm 1.7^{\mathrm{a}}$ & $15 \pm 0.0^{\mathrm{c}}$ & $29 \pm 0.8^{\mathrm{d}}$ & $18 \pm 1.3^{\mathrm{e}}$ \\
\hline & $\mathrm{M}$ & $30 \pm 0.0^{\mathrm{a}}$ & $13 \pm 4.4^{\mathrm{b}}$ & $28 \pm 1.7^{\mathrm{ab}}$ & $15 \pm 5.0^{\mathrm{ab}}$ & $29 \pm 0.8^{\mathrm{d}}$ & $14 \pm 3.0^{\mathrm{e}}$ \\
\hline & Total & $29 \pm 0.6^{\mathrm{d}}$ & $17 \pm 1.7^{\mathrm{e}}$ & $28 \pm 0.8^{\mathrm{d}}$ & $16 \pm 1.6^{\mathrm{e}}$ & $29 \pm 0.5^{\mathrm{d}}$ & $16 \pm 1.1^{\mathrm{e}}$ \\
\hline
\end{tabular}

a,b,c Row means within sire lacking common superscript letters differ $(P<0.05)$.

${ }^{\mathrm{d}, \mathrm{e}}$ Row means within totals lacking common superscript letters differ $(P<0.05)$.

${ }^{1}$ Using a split-ejaculate technique, semen from 3 Holstein sires was cryopreserved in egg yolk citrate and nonheated whole milk extenders. Straws from each sire by extender combination were thawed in a $37^{\circ} \mathrm{C}$ water bath or air-thawed by wrapping in a paper towel and placing on a $37^{\circ} \mathrm{C}$ warming plate for $3 \mathrm{~min}$. All straws were incubated for $1 \mathrm{~min}(0 \mathrm{~h})$ or $3 \mathrm{~h}$ in a $37^{\circ} \mathrm{C}$ water bath before visual estimation of percentage motile sperm. Procedures were performed in triplicate. 
Table 6. Least squares means ANOVA of treatment effects on conception rates (experiment 2).

\begin{tabular}{lllll}
\hline Source & df & Sum of squares & $F$ ratio & $P>F$ \\
\hline Sire & 2 & 1.2009210 & 2.8758 & 0.06 \\
Extender & 1 & 0.0016377 & 0.0078 & 0.93 \\
Thaw method & 1 & 0.5769322 & 2.7631 & 0.10 \\
Sire $\times$ extender & 2 & 0.1216498 & 0.2913 & 0.75 \\
Sire $\times$ thaw method & 2 & 0.1623188 & 0.3887 & 0.68 \\
Extender $\times$ thaw method & 1 & 0.0425447 & 0.2038 & 0.65 \\
Sire $\times$ extender $\times$ thaw method & 2 & 1.5598046 & 3.7352 & 0.02 \\
Season & 1 & 0.5260704 & 2.5195 & 0.11 \\
Milk production & 4 & 0.2841390 & 0.3402 & 0.85 \\
Lactation & 2 & 1.1868760 & 2.8421 & 0.06 \\
Days in milk & 2 & 0.8995479 & 2.1541 & 0.12 \\
\hline
\end{tabular}

similarities in semen processing procedures, extender preparation, freezing procedures, and air-thaw methodologies between experiments, procedures were not identically replicated in each of the 2 studies. Use of palpated pregnancy rate of lactating cows in the present study was likely a more sensitive bioassay of fertility than was the nonreturn rate of the more highly fertile virgin heifers used in the study of Kaproth (2005a,b) (Salisbury and VanDemark, 1961; Saacke, 1998). In the present study, the sire $\times$ extender $\times$ thaw method interaction was found to significantly influence conception rates. Sire $\times$ thaw method interactions, however, were not considered in the statistical analysis of Kaproth et al. (2005a,b). Such interactions imply caution must be exercised when extrapolating the results of studies involving a small number sires to the larger population as important interactions may often go undetected simply due to random sampling error. Even greater caution should likely be exercised when interactions are not considered.

Although sire interactions tend to imply that optimum fertility is likely achieved when semen extenders, processing procedures, and perhaps thawing procedures are tailored to the individual sire, this becomes impractical in the commercial setting, especially with respect to sire-specific semen handling protocols. Tailoring extender formulations and processing procedures for certain highly valuable sires is simple enough for laboratory personnel, but due to the large numbers of sires available and numbers of personnel handling semen in the field, standard operating procedures for semen thawing and handling are deemed extremely important (Chandler et al., 1984). As evident in the present study, there is no question that certain sire $x$ extender combinations can tolerate air-thaw better than others, and with little to no reduction in conception

Table 7. Effects of sire, extender type, and thaw method on conception rates (experiment 2).

\begin{tabular}{|c|c|c|c|c|}
\hline \multirow[b]{2}{*}{ Sire } & \multirow[b]{2}{*}{ Extender type } & \multicolumn{2}{|c|}{ Thaw method ${ }^{1}$} & \multirow[b]{2}{*}{ Total } \\
\hline & & Water & Air & \\
\hline K & $\begin{array}{l}\text { Egg yolk citrate } \\
\text { Nonheated milk } \\
\text { Total }\end{array}$ & $\begin{array}{ll}38 & (16 / 42) \\
30 & (12 / 40) \\
34 & (28 / 82)\end{array}$ & $\begin{array}{ll}29 & (12 / 41) \\
33 & (13 / 39) \\
31 & (25 / 80)\end{array}$ & $\begin{array}{ll}34 & (28 / 83) \\
32 & (25 / 79) \\
33 & (53 / 162)\end{array}$ \\
\hline $\mathrm{L}$ & $\begin{array}{l}\text { Egg yolk citrate } \\
\text { Nonheated milk } \\
\text { Total }\end{array}$ & $\begin{array}{l}34(13 / 38) \\
52(17 / 33)^{\mathrm{a}} \\
42(30 / 71)^{\mathrm{c}}\end{array}$ & $\begin{array}{l}33(14 / 42) \\
24(10 / 41)^{\mathrm{b}} \\
29(24 / 83)^{\mathrm{d}}\end{array}$ & $\begin{array}{ll}34 & (27 / 80) \\
37 & (27 / 74) \\
35 & (54 / 154)\end{array}$ \\
\hline M & $\begin{array}{l}\text { Egg yolk citrate } \\
\text { Nonheated milk } \\
\text { Total }\end{array}$ & $\begin{array}{ll}36 & (13 / 36)^{\mathrm{a}} \\
23 & (9 / 39) \\
29 & (22 / 75)\end{array}$ & $\begin{array}{l}15(7 / 46)^{\mathrm{b}} \\
29(11 / 38) \\
21(18 / 84)\end{array}$ & $\begin{array}{ll}24 & (20 / 82) \\
26 & (20 / 77) \\
25 & (40 / 159)\end{array}$ \\
\hline Total & $\begin{array}{l}\text { Egg yolk citrate } \\
\text { Nonheated milk } \\
\text { Total }\end{array}$ & $\begin{array}{ll}36 & (42 / 116)^{\mathrm{c}} \\
34 & (38 / 112) \\
35 & (80 / 228)^{\mathrm{c}}\end{array}$ & $\begin{array}{ll}26 & (33 / 129)^{d} \\
29 & (34 / 118)^{d} \\
27 & (67 / 247)^{d}\end{array}$ & $\begin{array}{ll}31 & (75 / 245) \\
31 & (72 / 230) \\
31 & (147 / 475)\end{array}$ \\
\hline
\end{tabular}

\footnotetext{
${ }^{\mathrm{a}, \mathrm{b}}$ Row means having different superscript letters differ $(P \leq 0.05)$.

${ }^{\mathrm{c}, \mathrm{d}}$ Row means having different superscript letters differ $(P \leq 0.10)$.

${ }^{1}$ Using a split-ejaculate technique, semen from 3 Holstein sires was cryopreserved in egg yolk citrate and nonheated whole milk extenders. Straws were thawed in a $35^{\circ} \mathrm{C}$ water bath for $45 \mathrm{~s}$ or removed from the liquid nitrogen storage vessel, wiped with a paper towel, and placed directly in the insemination gun (airthaw). Assembled guns were wrapped in a paper towel and placed inside the AI technician's clothing for transport to the cow.
} 
rates. These data, however, support previously published studies that imply warm water-thaw is more universally conducive to optimal sperm survival than is air-thaw (Berndston et al., 1976; Senger, 1980; Chandler et al., 1984).

Although numeric differences in conception rates between extenders were observed within sires and thaw methods, overall results support previous unpublished findings that conception rates of NHWM extender are comparable $(P=0.93)$ with those of EYC extender. These data also are consistent with published studies indicating comparable conception rates are achieved with HWM and EYC extenders (Foote, 1978; Schenk et al., 1987).

Across sires, extenders, and thawing methods, sperm motility after $3 \mathrm{~h}$ of incubation tended to correlate positively with conception rates $(\mathrm{r}=0.55, P=0.06)$. Motility at $0 \mathrm{~h}$ postthaw, however, displayed no evidence of correlation with conception rates $(\mathrm{r}=0.10, P=0.76)$. These data are consistent with those from other studies indicating that postthaw thermal stress enhances sensitivity of sperm viability assays to detect latent sperm injury that may negatively influence conception and thereby increase correlations with fertility data (Linford et al., 1976; Saacke et al., 1980; DeJarnette et al., 2000).

Conception rates tended $(P<0.10)$ to be less in second-lactation cows $(27 \%, 56 / 208)$ than in first-lactation cows $(35 \%, 62 / 178)$ or cows in their third or greater lactation $(33 \%, 29 / 89)$. Conception rates were numerically greater $(P=0.12)$ in cows 60 to $75 \mathrm{DIM}$ at AI $(37 \%, 77 / 210)$ than in cows 76 to $150(27 \%, 35 / 129)$ or cows $>150$ DIM $(26 \%, 35 / 136)$ at AI. Relative herd-mate deviation for milk production had no effect $(P=0.85)$ on conception rates in the present study. Conception rates in fall $2003(35 \%, 88 / 250)$ were numerically greater $(P=0.11)$ than those observed in spring 2004 $(26 \%, 59 / 225)$.

\section{Synopsis}

The current recommendation for air or pocket-thaw procedures seems to originate from an experiment conducted in the late 1960s when AI centers in the United States were investigating the potential benefits of a transition from glass ampules to plastic French straws as a packaging method for extended bovine semen (Bean, 1972). As a function of differences in surface to volume ratios and freezing rates, optimum postthaw sperm survival is achieved with $5^{\circ} \mathrm{C}$ ice water thaw of glass ampules and with faster $35^{\circ} \mathrm{C}$ water thaws of French straws. However, Bean (1972) became aware that some technicians participating in these early field trials were deviating from protocol and achieving ac- ceptable nonreturn rates when using air-thaw. Although the air-thaw procedure unquestionably results in slower and more variable thaw rates due to poor thermal conductivity and varying ambient air temperatures at the time of thawing, the simplicity of the procedure was enticing enough to evaluate as an alternative to water-thaw. It is of interest to note that the extender used in these initial studies of Bean (1972) was an EYC extender very similar to that used in the present study. Although the effects of thaw method on sperm viability were not reported, comparable nonreturn rates were achieved with air- and warm water-thaw of semen processed in French straws. Berndston et al. (1976) subsequently reviewed the data of Bean (1972) and similar studies comparing the effects of thaw method on sperm viability and fertility in both EYC and HWM extenders. They concluded that slower thaw rates result in reduced sperm survival and are not recommended, even though comparable conception rates may be achieved if sperm dosage is sufficiently high to maintain above threshold sperm numbers. Results of the present study are consistent with their conclusions (Berndston et al., 1976).

It is important to note that none of the air-thaw treatments in the present study directly replicated the pocket-thaw procedure, which recommends wrapping straws in a paper towel and placing them in the breast pocket of the technician's shirt or coveralls for $3 \mathrm{~min}$ before gun assembly (Kaproth et al., 2002, 2005a,b). Choice of the $37^{\circ} \mathrm{C}$ warming plate for air-thaw before laboratory evaluation of sperm motility was selected to facilitate a faster, more uniform, and presumably more optimum, thawing rate. Direct loading of straws into the insemination gun (no shirt-pocket incubation) during the on-farm field trial was a function of the technician's interpretation of instructions and likely yielded a slower and more variable thaw rate than did the pocket-thaw procedure. This errant interpretation of the pocket-thaw procedure is relatively common among inseminators (personal experience of the authors) and reinforces the importance of uniformity, consistency, and proper training in semen-handling procedures. Nonetheless, results of the present study do not preclude the possibility that alternative freezing protocols and extender formulations to those used herein may facilitate greater sperm tolerance to air-thaw procedures. Therefore, our results may not be directly comparable with those obtained by other researchers. Rather, our data emphasize that, because of these differences in processing procedures, inseminators must ascertain that straws are always thawed according to the recommendations of the laboratory that processed the semen.

\section{CONCLUSIONS}

Interactions of straw-thawing method with both sire and extender type indicate that conditions can be cre- 
ated that facilitate greater sperm tolerance of air-thaw procedures. Among all significant interactions of thaw method with sire and (or) extender type, air-thaw was consistently associated with the lesser measure of postthaw sperm motility or conception. Nonetheless, straws should always be thawed according to the recommendations of the organization that processed the semen. Incubation of straws for $3 \mathrm{~h}$ at $37^{\circ} \mathrm{C}$ magnified differences in sperm motility induced by thaw method and resulted in a greater degree of correlation with conception rates than motility estimates immediately after thawing.

\section{ACKNOWLEDGMENTS}

The authors thank Larry Jarvis, Jr. and the staff of Teabow Farms, Inc. (Walkersville, MD) for use of their cattle, labor, and expertise in conducting the on-farm field trial (experiment 2). The authors thank Beverly Cotton, Marysville, $\mathrm{OH}$, for assistance with in vitro semen quality evaluation. We also thank Matt Hershey, Lancaster, PA, and Keith Meador, Frederick, MD, for their assistance in organization and supervision of this project.

\section{REFERENCES}

Bean, B. 1972. Laboratory procedures and field trial results with straws. Pages 77-81 in Proc. 4th NAAB Tech. Conf. Artif. Insem. Reprod. NAAB, Columbia, MO.

Berndston, W. E., B. W. Pickett, and C. D. Rugg. 1976. Procedures for field handling of bovine semen in plastic straws. Pages 5160 in Proc. 6th NAAB Tech. Conf. Artif. Insem. Reprod. NAAB, Columbia, MO.

Chandler, J. E., R. W. Adkinson, and R. L. Nebel. 1984. Thawing optimums for bovine spermatozoa processed by three methods and packaged in Continental and French straws. J. Dairy Sci. 67:398-404.

DeJarnette, J. M., D. A. Barnes, and C. E. Marshall. 2000. Effects of pre- and post-thaw thermal insults on viability characteristics of cryopreserved bovine semen. Theriogenology 53:1225-1238.
Flipse, R. J., S. Patton, and J. O. Almquist. 1954. Diluters for bovine semen. III. Effect of lactenin and lactoperoxidase upon spermatozoan livability. J. Dairy Sci. 37:1205-1211.

Foote, R. H. 1978. Extenders and extension of unfrozen semen. Pages 442-493 in Physiology of Reproduction and Artificial Insemination of Cattle. 2nd ed. G. W. Salisbury, ed. W. H. Freeman and Co., San Francisco, CA.

Kaproth, M. T., J. E. Parks, G. C. Grambo, H. E. Rycroft, J. A. Hertl, and Y. T. Gröhn. 2002. Effect of preparing and loading multiple insemination guns on conception rate in two large commercial dairy herds. Theriogenology 57:909-921.

Kaproth, M., H. Rycroft, G. Gilbert, G. Abdel-Azim, B. Putnam, S. Schnell, R. Everett, and J. Parks. 2005a. Effect of semen thaw method on conception rate in dairy heifer herds. Reprod. Fertil. Dev. 17:157. (Abstr.)

Kaproth, M. T., H. E. Rycroft, G. R. Gilbert, G. Abdel-Azim, B. F. Putnam, S. A. Schnell, R. W. Everett, and J. E. Parks. 2005b. Effect of semen thaw method on conception rate in four large commercial dairy heifer herds. Theriogenology 63:2535-2549.

Linford, E., F. A. Glover, C. Bishop, and D. L. Stewart. 1976. The relationship between semen evaluation methods and fertility in the bull. J. Reprod. Fertil. 47:283-291.

Robbins, R. K., R. G. Saacke, and P. T. Chandler. 1976. Influence of freeze rate, thaw rate and glycerol level on acrosome retention and survival of bovine spermatozoa frozen in French straws. J. Anim. Sci. 42:145-154.

Rodriguez, O. L., W. E. Berndtson, B. D. Ennen, and B. W. Pickett. 1975. Effect of rates of freezing, thawing and level of glycerol on the survival of bovine spermatozoa in straws. J. Anim. Sci. 41:129-136.

Saacke, R. G. 1998. AI fertility: Are we getting the job done? Pages 6-13 in Proc. NAAB 17th Tech. Conf. Artif. Insem. Reprod. NAAB, Columbia, MO.

Saacke, R. G., W. E. Vinson, M. L. O'Connor, J. E. Chandler, J. K. Mullins, R. P. Amann, C. E. Marshall, R. A. Wallace, W. N. Vincel, and H. C. Kellgren. 1980. The relationship of semen quality and fertility. Pages 71-78 in Proc. 8th Tech. Conf. Artif. Insem. Reprod. NAAB, Columbia, MO.

Salisbury, G. W., and N. L. VanDemark. 1961. Significance of Semen Quality. Pages 359-379 in Physiology of Reproduction and Artificial Insemination of Cattle. 1st ed. W. H. Freeman and Co., San Francisco, CA.

Schenk, J. L., R. P. Amann, and C. H. Allen. 1987. Effects of extender and insemination dose on post thaw quality and fertility of bovine sperm. J. Dairy Sci. 70:1458-1464.

Senger, P. L. 1980. Handling frozen bovine semen - Factors which influence viability and fertility. Theriogenology 13:51-62.

Thacker, D. L., and J. O. Almquist. 1953. Diluters for bovine semen. I. Fertility and motility of bovine spermatozoa in boiled milk. J. Dairy Sci. 36:173-180. 